\title{
A social scientific study of the significance of the jubilee in the New Testament1
}

\author{
Gert Volschenk \& Andries van Aarde \\ Research Associate: Department of New Testament Studies \\ University of Pretoria
}

\begin{abstract}
This social scientific study of the Biblical jubilee focuses primarily on the jubilee as a metaphor within the framework of engaged hermeneutics. The jubilee was a symbol of transformation and emancipation. The article shows the significance of the jubilee in the New Testament as interpreted within the context of the reign of God and salvation in Jesus Christ. The liberation from enslavement pertains to all levels of human existence, including socio-economic and political interrelationships. The study demonstrates conflicting perceptions of land tenancy in an ancient economy that resulted in the exploitation and enslavement of peasants and their families. The constructs of the advanced agrarian society and the preindustrial city are used as heuristic models for the interpretation of data.
\end{abstract}

\section{INTRODUCTION}

This social scientific study of the significance of the jubilee in the New Testament focuses on the jubilee as a metaphor and symbol in contextual theology. The pragmatic consequences of the jubilee are emphasised in the context of engaged hermeneutics. The jubilee is interpreted within the context of the Kingdom of God and salvation in Jesus Christ.

The Gospels do not refer directly to the jubilee. Liberation or redemption includes all levels of human existence, including the socio-economic and political levels.

1 This article is based on part of G J Volschenk's DD dissertation, entitled "Eksegeties-metodologiese vooronderstellings van die ondersoek na the ekonomie in the leefwêreld van Matteus: Toegepas op land, grondbesit en die jubilee." The dissertation was prepared under the supervision of Prof Dr A G van Aarde, Faculty of Theology, University of Pretoria (2001). 
God's reign breaks the dehumanising pattern of enslavement at all levels of human existence. Sociology of knowledge emphasises the dialectic relationships between the individual and society. Interpreting the Bible from this perspective forms part of the social scientific approach to exegesis. Such a sociology of knowledge study evolves new perspectives relevant to an understanding and applications of the laws of the jubilee. The dialectic tension between the descriptive (what is) and the normative (what should be) in the construction of the universe, particularly in an interpretation of the jubilee, opens up a new perspective on the place and function of the Biblical jubilee in land theology. A social scientific study of the Biblical jubilee reveals some of the conflicting perceptions of land ownership that prevailed the economy of ancient Israel. The consequences of these conflicting perceptions regarding the ownership of land were debt (enslavement) and the exploitation of peasants and their families by absentee landowners. This sociology of knowledge study aims to provide a broad frame of reference for an understanding of the ancient economy. Existing models are used to counter the fallacies of anachronism and ethnocentrism.

\section{THE BIBLICAL JUBILEE AS A SYMBOL OF TRANSFORMA- TION AND EMANCIPATION}

Ringe's (1985) work Jesus, liberation and the Biblical jubilee represents a transition between literary criticism and social scientific criticism. Her study is a combination of literary criticism and sociological analysis. The combination of these two methods overcomes two dangers. Firstly, the focus on the performative power of the language of the jubilee ensures that the jubilee is not merely seen as an ancient, old-fashioned social proposition. Secondly, the metaphor is more than a mere social proposition because the complexities of the concept "jubilee" require some practical application. Ringe (1985) is a feminist and liberation theologist who works within a paradigm of contextual theology. Her study focuses on "the power of concrete language in particular concrete form" (Ringe 1985:ix). The language of the Biblical jubilee image has transformational and emancipatory dynamics in new contexts. She sees that

the social proposal of Jubilee has come to function as a powerful metaphor, so that what was sociology now takes on literary rhetorical power well beyond a 
specific social proposal. This means it is no longer a flat social proposal to be implemented or rejected, but it is now a linguistic act that continues to have dangerous power in all sorts of contexts that are neither legislative nor didactic. As a metaphor of dangerous power, it cannot be reduced and contained simply as a social proposal.

(Ringe 1985:x)

The image of the Biblical jubilee looks forward, not only to the New Testament, but to new contexts. "The metaphor (social proposal become liberated metaphor) as elusive and evocative social possibility continues to push forward into the life of the community wherever the text is taken seriously" (Ringe 1985:xi). According to Brueggemann (1985:xi), the text operates in the service of transformational liberation, without serving any ideology. The problem with this statement is that liberation theology and/or feminist theology are in themselves ideologies. According to Ringe (1985:1-5), the Biblical jubilee is more than a mere metaphor, parable or symbol. It is an image, which is an comprehensive term. Some of the attributes of an image are these:

- images shape reality;

- images are based on specific social, cultural and political contexts;

- images are capable of changing a person's world;

- images promote interdisciplinary research;

- images have to be interpreted.

Ringe $(1985: 10,11)$ is a proponent of what is called engaged hermeneutics. The conservative function of images in Christology has long been dominant in the development of church tradition and dogma. The transcendental, other-worldly aspects of Christ have, according to Ringe (1985:11), been overemphasised at the expense of a more pragmatic involvement in the public, political and social dimensions of life. Redemption has only affected the human soul. 
As people have sought ways to make the audacious claim that in the human being Jesus, God's ultimate intent for humankind is known, images accenting the transcendent, otherworldly aspects of Christ have multiplied. At times they have all but eclipsed images accenting the essential fact that this one called the Christ was human as we are. The accent on the otherworldly and transcendent dimensions of the Christ has its parallel in the devaluing of physical, historical life, and in the denying of the importance of one's involvement in the activities and choices of the secular political, social, and economic world.

(Ringe 1985:10, 11)

Ringe (1985:11) calls the emphasis on the transcendental and on a lack of involvement in more pragmatic aspects of life a hierarchic model. The hierarchic model supports and promotes dominant patterns and oppression. In that case, the Christian message becomes apolitical and estranged from the world. The focus of alternative models is a redemptive vision of another humankind and world, and the liberating acts of Jesus carry this message. Moreover, Ringe $(1985: 12,13)$ emphasises the historical context in which and from which the jubilee texts developed.

The point is not to secure irrefutable data about Jesus's life, but rather to recognize within their cultural matrix both the sayings and words, and the related perception of Jesus as the Christ, that the text is intended to convey.

The details of the stories by which Jesus is presented as the Christ are not coincidental. Not only do they [embed this] ... confession in a particular historical and cultural context, but they also are combined in story form in a way that confronts our human situation with transformative power.

The transformational power of the text or message reduces the power of enslaving institutions and liberates us for a struggle of liberation, "to participate with Christ and with the poor, the oppressed, and the disenfranchised of our world in struggles for liberation" (Ringe 1985:14). The images of liberation in the jubilee create two dangers, namely the fallacies of anachronism and reductionism. Ringe (1985:14) states clearly 
that a literal translation of the jubilee images to identify with modern political and social programmes are guilty of the anachronistic fallacy. The fallacy of reductionism refers to a tendency to select only those images that do not threaten our position of privilege (see Oakman 1986:xiii).

\section{A LITERARY CRITICAL AND SOCIOLOGICAL STUDY OF THE JUBILEE}

\subsection{The dominion and sovereignty of God}

Liberty is the underlying principle in the Biblical jubilee. In Isaiah 61:1-2 three images are used that are typical of the jubilee. First, there is the annunciation of God's reign by the messenger anointed by the Spirit of God. Second, there is the preaching of the good news (gospel) to the poor. The poor are mentioned in several contexts in the Gospels, which emphasises the importance of the poor in the ministry of Jesus and his identity as the Christ. In the beatitudes (Mt 5:3-6) and table community (Lk 14:1-14), the poor are among the groups who receive the blessing of God's eschatological reign. Finally, there is the proclamation of liberation from various forms of imprisonment and slavery. Jesus and his message announce the end of the old order - an order characterised by oppressive structures, systems and institutions - and the beginning of a new order. The jubilee shows what happens to a person who encounters God's reign.

Ringe (1985:28) interprets the confession of the sovereignty of God as having practical implications in the socio-economic domain: "To confess God as sovereign includes caring for the poor and granting freedom to those trapped in a continuing cycle of indebtedness. God's sovereignty is presented as a fact bearing on people's daily life and structuring their relationships with one another and with the rest of the created order." Ringe's (1985:32) exegetical study confirms the pragmatic effects of the confession of God's sovereignty:

... traditions associated with the Jubilee appear to affirm two things. The first is that God is sovereign over Israel, both in actual fact and in eschatological 
hope. The second is that the structures of economic and social life must embody the people's affirmation of God's sovereignty. In other words, God's reign and humankind's liberation go hand in hand.

\subsection{The link between the Gospels and the Biblical jubilee}

The Synoptic Gospels reflect images of the jubilee that were contributed by the evangelists themselves. Moreover, the pericopes are emphasised by references to images of the jubilee and by the context thereof in the Gospels. Ringe (1985:88) adds:

In addition to occurring in all of the sources and in the contributions of the evangelists, Jubilee images have been shown to occur in a variety of forms within the larger sources. These images form the core sayings in several pronouncement stories and are found in parables, in the Lord's Prayer, and in several teaching passages. They also figure in accounts of Jesus' table community with outcasts and sinners.

The references in Jesus' ministry and words to the Biblical images of the jubilee are vague and indirect. It is also not clear whether Jesus deliberately and consciously proclaimed a jubilee message. According to the gospel writers, Jesus proclaims the coming of God's eschatological reign. The Gospels proclaimed to the poor a message of liberation from various forms of enslavement, at a social, economic and political level. However, there is no direct reference to the Biblical jubilee in the Gospels. The testimony of the jubilee is a combination of factors. It consists of interwoven information and interpretation. The texts proclaim the theological importance of what Jesus said and did and the implications thereof for the confession of Jesus as the anointed of God. The Christological aim serves as a measure for the evaluation of texts from the Old Testament. The interaction between the text, its context and hermeneutics can be described as follows:

... the critical disciplines and questions that we bring to the study of the ancient texts and societies become part of our context, just as do our social, political, economic, and cultural identities. We are therefore addressed by the 
Jubilee traditions both in ways consistent with their original framing and in ways independent of and even foreign to it. The power of these images to help us say what it means to confess Jesus as the Christ, as well as to confront our assumptions concerning values and priorities in our daily lives, becomes a vehicle by which we read forward or interpret from the biblical traditions into our own situation.

(Ringe 1985:36)

Discipleship, or, put in another way, our relationship with Jesus and the Gospels, is indissolubly linked to our relationship with and continuous care for the outcasts (Ringe 1985:64; cf Mk 2:17//Lk 5:32//Mt 9:12). The Gospels are God's good news for the poor. There is an indirect link between the poor and the gospel that is proclaimed. The poor always include the economically poor, as well as social outcasts and physically handicapped people. This prevents an overemphasis on the economically poor. The anointment of Jesus in Bethany (Mt 26:6-13) again stresses the spreading of the good news of Jesus to the poor. The preaching of the gospel is closely linked to the involvement with social outcasts in Matthew 25:31-49. This text suggests that the test of faith at the Final Judgement is our involvement with the poor and oppressed. The links between the Gospels and the jubilee can be summarised as follows:

What appears to have occurred is a three-step process. First, Jubilee images and traditions appear to have played a major role in Jesus' own activity and message. In the second step of the process, the early church, prompted and focused by the Easter experience that gave it birth, drew on a variety of images associated with Jesus' own message in order to proclaim Jesus' identity as the Christ and his saving significance for all believers. Later on, as the early church built the traditions concerning Jesus' life and ministry into the Gospel accounts, Jubilee references again appeared more explicitly. By then those images carried a double significance, including both their original connection to Jesus' proclamation of God's reign and their subsequent role in the christological confession of the early church.

(Ringe 1985:89) 


\subsection{Liberation and forgiveness or absolution}

The message of liberation and forgiveness or absolution in the jubilee traditions refers to the manumission of slaves and the remission of debt ( $\mathrm{Lv} 25)$. Liberty is proclaimed to

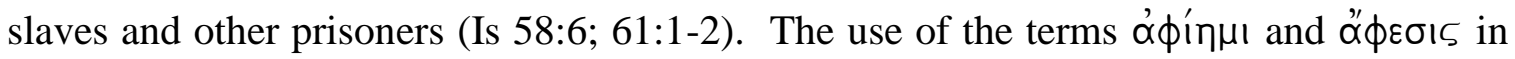
the Septuagint is similar to the use of the words in classical Greek. The words refer, on the one hand, to forgiveness in the religious or ethical sense and, on the other hand, the term forgiveness is also used in a broader sense to emphasise the covenant or a contract. In the New Testament the term $\alpha \phi^{\prime} i_{\eta} \mu$ is used to refer to the remission of monetary debt (Mt 18:27, 32), being freed from captivity (Lk 14:18) and absolution from sin (Mt 6:1415; Mk 2:5-10; 3:28; Lk 7:47-50).

Forgiveness and liberation in all areas of life are some of the most important characteristics of the human encounter with God's dominion. The Kingdom of God breaks down all forms of enslavement in all spheres of life - social, political and economic. The term the poor refers to all categories of enslavement of the old order (human rule versus God's reign $-\mathrm{GV}$ ). Jesus breaks down all the bonds that rob people of a place in their community. Some pericopes in the Gospels (for example, Lk 7:36-50) reflect the jubilee images of a return to God which occur in Leviticus 25 and Isaiah 61 and which refer to liberation from captivity, as well as the celebration of God's eschatological reign as it is manifested in Christ (see Ringe 1985:71).

The meaning of forgiveness in Jesus' message should be understood within the contexts of the parable of the unforgiving slave (Mt 18:21-35) and the forgiveness we ask for in the Lord's Prayer (Mt 6:14-15; Lk 11:4; Mk 11:25-26). In the parable, the central issue is human choice between the rule of the old order and the Kingdom of God. Living the principle of mutual remission of debt implies that the new economy of mercy and freedom triumphs over the old order of enslavement and obligations that result in debt or slavery. Resistance to making the choice of mutual remission of debt means excluding oneself from the reign of God (Ringe 1985:76, 77; see Crosby 1988:188).

Ringe (1985:79, 80) regards the Lord's Prayer as a prayer focused on the establishment of God's reign on earth. The petition for forgiveness and remission of debt is an integral part of God's reign and is a declaration of the intention to participate in the new economy of God, where the individual simultaneously forgives and is forgiven. The image of God's reign reinforces the fact that this reign eliminates dehumanising patterns 
at all levels of human existence and confirms God's reign over all life and life in its totality. This good news is also meant for social outcasts (compare with Jesus' table community), and for all those who are trapped in the vicious cycle of financial debt and low incomes. Forgiveness (liberation or manumission) implies a general and economic change in relations and behaviour made possible by God's reign. Jesus, the Christ,

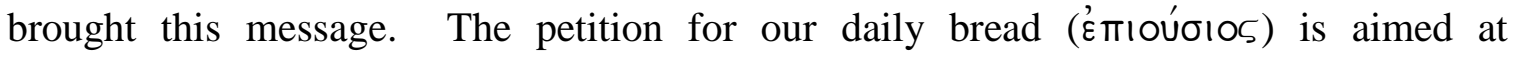
supporting or saving human life and the focus is on the providence of God. It therefore reflects the bread of the messianic last supper and the manna that God bestowed upon the Israelites during their wandering through the desert (Ex 16:4; Ps 78:24). The petition indirectly reflects images of the jubilee and therefore brings good news to the poor (Ringe 1985:83-84).

\section{A SOCIOLOGY OF KNOWLEDGE STUDY OF THE BIBLICAL JUBILEE}

Fager (1993:13) provides an overview of research regarding the Biblical jubilee. The most comprehensive sociological study of the jubilee to date was done by Robert North, and is set out in his Sociology of the Biblical jubilee. The study tends to focus too much on the historical and social factuality of the jubilee. Other works tend to overlook exegetic aspects. Some studies worth noting are those by R Gnuse (1985) and C J H Wright (1990). According to Fager (1993:13), Gnuse and Wright do not pay enough attention to the world view of ancient Israel. Changing perceptions of the jubilee are part of a comprehensive understanding of the world and of the way in which people live in their worlds. The jubilee should be interpreted within the context of the moral world view on which it was based. Flanagan (1988:53-72) comments as follows on some of the problems arising from studies of a social world view:

Social world studies do not offer a single method or theory in the usual sense of the terms. Their dependence on standard biblical methodologies, archaeology, and comparative sociology make them derivative and eclectic in ways that defy methodological purity .... Social world studies treat every society as unique, but the comparisons inject pragmatism, positivism, and 
Massouri style "show-me-ism" that both expects and suspects consistencies in human behaviour.

The social sciences promote the reader's understanding of the text against the backdrop of a particular social system by using existing theories or models (Malina 1982:239; Fager 1993:15). The text is a scenario:

Readers couple scenes or schemes from the text with settings, episodes or models which already exist in their minds and are derived from their own experience. While the text may provide certain alterations to those settings, episodes or models, the author uses a familiar "domain of reference", or social world, to evoke more or less predictable responses. Knowledge of the original reader's domain of reference is necessary in order to understand the meaning intended within the text.

(Malina 1982:240)

Sociology of knowledge is based on the assumption that social location affects a reader's perspective. In its turn, this perspective determines the meaning attached to objects, and to language. Sociology of knowledge presupposes a dialectic relationship between the individual and society. Humans create an ordered world. The dialectic process can be described as follows:

- people create a society;

- the society comes to be seen as objective; and

- the society shapes people.

The creation of a world is a structuring process of classifying objects and events in a coherent and comprehensible structure. Everyone participates in the dialectic process, so that the world becomes predictable and habitable (see Berger \& Luckmann 1966:5-7). Fager (1993:17) describes this dialectic process as follows: 
Once a world is created, the objects of that world, either material (e.g. tools) or nonmaterial (e.g. language), take on existence independent of the absolute control of their creator, humanity, and thus become objective and shareable. As these objects are shared within a society, meanings are attributed to them, and those meanings become a taken-for-granted knowledge which is then mediated throughout the society and to the next generation [cf the jubilee GV]. However, since the creation and maintenance of a world constitute a dialectic process, in which people influence the social world as well as being shaped by it, there is always the tendency for people to attribute new meanings to familiar objects.

Every individual, generation and group looks at the world from his/her/their own perspective, which may differ a little or radically from other perspectives. A shared frame of reference makes it possible for people to live together within the physical world. Every society has its own social basis which provides the processes and institutions that legitimise the social order. These shared meanings can be described as follows:

These processes and institutions provide the social forces which keep individual interpretations of the world within acceptable bounds. (By definition they are conservative in that they tend to conserve social order.) If that base is weakened or destroyed, the shared meanings that constitute the social world change, resulting in the formation of a new world.

(Fager 1993:18)

Members of society share meanings that transcend the workaday world. These meanings are related to abstractions and concepts that do not play a role in everyday life. Society uses symbols - everyday objects, people or events - used together and transcending everyday life (Fager 1993:19). Society creates such symbols and these symbols constitute a world (a dialectic process).

Religious worship was an important transcendental reality for Israel, and the jubilee is contextualised within this tradition. Religion may be defined as "the establishment, through human activity, of an all-embracing sacred order, that is, of a 
sacred cosmos that will be capable of maintaining itself in the ever-present face of chaos" (Berger 1969:51). This understanding of the universum makes it possible for people to know how to live within this world, because there is some form of continuity between the descriptive (that which is) and the normative (what should be) in the construction and maintenance of the universe (Fager 1993:19). Religious symbols often provide some indication of the links within a social community between what may be described as "what is" and "what ought to be" (Geertz 1973:89-127).

Radical change in the world causes incongruence (there is no correspondence whatsoever) between what is and what ought to be. Consequently, the community is under threat of moral chaos and social collapse. Social institutions no longer legitimise the social order and people lose their sense of trust in the cosmic order. The four phases of the legitimisation process are the following:

- the transmission of what is regarded as objective reality;

- support for this reality in terms of elementary theoretical assumptions;

- the development of specific theories by specialists to manage specific fields of knowledge; and

- the construction of a symbolic universe (see Berger \& Luckmann 1966:87-88; Fager 1993:20).

\subsection{Moral world view}

No moral world view can be separated from a more general understanding of the world as a whole. A moral world view has a number of particular attributes. Morality is a way of understanding the world within a framework of values. These values transcend the everyday human world, but they are also related to human experiences of objects in the everyday world. A community's symbols should promote this deeper grasp of values. A moral world view encompasses symbols that organise values into a system that guides uniform behaviour within a community. This system motivates individuals to act in accordance with the shared values of the community. If one understands the concepts of a moral world view, one can understand the ethics underlying the jubilee. 


\subsection{Three levels of meaning}

Mannheim (1952:44-46; Fager 1993:20) distinguishes three levels of meaning for any social phenomenon. The three levels should only be separated for analytical purposes. The distinction exposes the deeper levels of a world view expressed by an act or institution. According to Fager (1993:119), the period of captivity was a traumatic period during which the world of Israel collapsed, after the destruction of Jerusalem. Some groups described the events from a Jahwistic perspective of the universe (for example, the school of Ezekiel). The rise of Babylon and Cores as redeemer resulted in the emergence of a new society based on a particular world view. The priests based the system of land ownership (jubilee) on the traditions of the past. Fager (1993:120) does not focus on the jubilee as an eschatologically new era (as opposed to Ringe 1985:88), in which land is divided equally. The priests focus on the jubilee system in the contemporary world as a self-correcting, continuous redistribution of land ownership in accordance with divine will. The jubilee is based on a moral world view that emerges clearly from the interrelations between three levels of meaning. The following three levels of meaning can be identified:

\subsubsection{Objective meaning}

The first level of meaning is the objective level. At this level, the focus is on the purely sociological data of a phenomenon. In any form of behaviour, this level refers to the events that are perceptible by the senses. When the focus is on an institution, this level refers to the real structure and laws or rules of the institution. Fager (1993:120) concludes that the jubilee was contrasted with the Canaanite system of land ownership. The Canaanites regarded land as a commodity that could be bought or sold for profit. By contrast, the jubilee regards land as the inalienable heirdom of peasant families that practised subsistence farming on the land. The family was an independent social entity that could be distinguished from the community as a whole. These are obviously conflicting views of land ownership.

\subsubsection{Expressive meaning}

The second level is expressive meaning. This level refers to the purpose of the individual role-players or agents involved in a social phenomenon. Different individuals or groups 
attempt to express different meanings by behaving in the same way or by participating in the same institution(s). The expressive meaning is very subtle and various clues have to be sought. These clues indicate exceptions; for example, jubilee laws that do not imply land ownership or divine ownership.

When they returned, the priests intended to establish a just society. They attempted to maintain their own power, but also to provide land for the returning Israelites. They used old traditions to legitimise this new society. The theological guarantees provide divine sanction for the jubilee laws. They did not intend to build an eschatological utopia that had no relation to their reality.

\subsubsection{Documentary meaning}

This meaning refers to the meaning of every social phenomenon. It can be distinguished on the basis of the factual surface details of texts and the intentions of the authors. This world view underlies a community's way of life at such a basic level that few people even realise that this world view exists and directs their lives. The jubilee has its own unique meaning based on the underlying world view. The documentary meaning is not completely independent of the objective and expressive levels of meaning. These three levels function simultaneously and dialectically with regard to one another. In view of the documentary meaning, one might conclude that divine ownership of the land is plausible. Research has shown the dialectic tension between the descriptive (what is) and the normative (what ought to be). Fager (1993:121) summarises this dialectic tension as follows: "The jubilee may be an ideal system which displays the existence of a divinely willed world that has not yet been actualized because of human failure to recognize its reality. We ought to actualize what really is." The dialectic tension is the solution to two opposing perceptions of the jubilee, namely the perception that it is impractical and difficult to implement, versus the desire for an eschatological utopia.

\subsection{The sociology of knowledge is weighed and ...}

Sociology of knowledge has made three important contributions to research on the jubilee. Sociology of knowledge proposes reasons for why certain traditions of land ownership developed, namely as an expression of the particular world view on which 
these traditions are based. It also explains why the jubilee developed to the form described in Leviticus 25. The tradition of the priests emphasises the reality of the jubilee as opposed to a utopia. The world view of the priests is characterised primarily by the notion of divine ownership of land. This view is part of the jubilee because it met the political and economic needs of the priests. Furthermore, sociology of knowledge has pointed out and addressed the dialectic tension between what is and what ought to be (the impractical versus an utopia). Finally, sociology of knowledge emphasises the essential interaction between the three levels of meaning as a dialectic relationship between the three levels. In the past, scholars tended to look too much for the meaning of the jubilee in the text in terms of the intention of an author. Sociology of knowledge uses exegetic research and other methods as a point of departure for trying to expand the exegetes' understanding of the ancient texts. This approach attempts to bridge the chasm between the twentieth and twenty-first centuries and pre-industrial ancient Israel.

\begin{abstract}
After all, the twentieth-century industrial world shares little with preindustrial ancient Palestine; therefore, the agrarian interests of the Judean priests could hardly be adopted by modern society. Yet we may share much with the priest's deepest convictions concerning a community's moral imperative toward its economical[ly] vulnerable members .... (we) will be able to apply these vulnerable truths to a world that seems always in need of assistance.
\end{abstract}

(Fager 1993:122)

Sociology of knowledge has been weighed and found too light. Sociology of knowledge is unable to prove any clear relation between the different elements of the Biblical jubilee. Hence, in this article, social scientific models of pre-industrial cities and advanced agrarian society are used to fill the gaps left by sociology of knowledge. These social scientific models serve as a comprehensive frame of reference for an understanding of the Biblical jubilee. They indicate various institutions in the economy and society of ancient Israel, as well as mutual relations. 


\section{SOCIAL SCIENTIFIC MODELS OF LAND OWNERSHIP}

Oakman (1986:xi-xiii) uses conceptual models to investigate the macro-economy and does quantitative research to study systems of taxation and production within broader economic relations. He studies land as one of three factors of production (land, labour and capital). He studies broad economic issues in Jesus' time, but he does not focus specifically on the issues of land and the jubilee. He argues that Jesus reacted in a coherent and logical way to the agrarian problems of first century Palestine. His study confirms the tendency to connect Jesus with the jubilee (cf Hollenbach 1985; Ringe 1985). The jubilee is an integral part of this first century agrarian economy.

The current sociological awareness in exegesis has also resulted in a range of sociological methodologies. The interdisciplinary nature of the research challenges dominant hermeneutic assumptions. Oakman (1986) examines the relation between Jesus' message of the Kingdom of God and socio-economic conditions in the first century. Oakman (1986) does not provide a comprehensive model for first century advanced agrarian economy. However, Oakman (1986:1-48) does use a comprehensive socio-historical frame of reference within which first century Palestinian economy is studied. The current scientific paradigm may be described as literary-formalist, because it examines the text only partially within the original historical context. According to Oakman (1986:2), Jesus' words and ministry emphasise new economic values and behaviour. The content of the new economy is based on Jesus' vision of God's coming kingdom (see Ringe 1985). Jesus' aim was to overcome the socially destructive consequences of the unequal distribution of wealth and control of material resources in Palestine.

Below, selected important aspects of Oakman's (1986) and Fiensy's (1991) work are discussed. Oakman (1986:50-56) describes different modes of land ownership from a social scientific perspective. Debt levels and the reasons for these levels are also set out clearly.

\subsection{The freeholdings of peasants}

Where a peasant was free and owned land, the peasant and his family lived on the land and controlled the yield of the fields. The basic expenditures on agricultural land can be 
divided into two broad categories: expenditures that were essential for the survival of the peasant and his family and expenses paid to others. These expenses were the following:

- Peasant families were subsistence farmers. Any peasant's first duty was to ensure that the yield met the needs of the family. These needs can be calculated in terms of the minimum number of calories required for human survival. The agricultural output required for survival is then the minimum amount of grain or harvest from the land needed to meet the family's energy/food requirements. This nutritional energy was put back into the system in the form of agricultural labour.

- The replacement fund consisted of money for seed (for planting) and sometimes food for livestock. This was the running capital needed for the agricultural unit to continue to operate from year to year. Production instruments (implements) also had to be maintained.

- The needs fund was reserved for trade and barter, so that any requirements of the family that the farm could not supply could be supplemented. This expenditure supported craftsmen and artisans and other specialists that met such requirements.

- The spending fund was essential for participation in the social order. The costs of weddings, local cult festivals and other social and religious obligations were covered by this fund.

- The fund for rent distinguished peasants from primitive agriculturists. Rent was the general term for surpluses that were recovered from peasants on the basis of asymmetric relations. Tax was different from rent. Tax had to be paid in addition to rent to the owner of a large estate, and a peasant could become subject to this landowner. Rent and tax were burdens additional to all the others.

\subsection{Different types of tenants}

Tenancy can be defined as subordinate socio-economic status expressed in terms of the laws governing land ownership (Oakman 1986:52-55; Fiensy 1991:80-84). There were two types of tenants: those with a written lease agreement and those without a written agreement. Furthermore, tenants could also be divided according to the nature of the landlord's returns: 
- tenants who paid a fixed rent rate, the hocar (payment in kind) and the socar (payment with money);

- tenants who paid a fixed rent in favours;

- sharecroppers, the aris, who paid a percentage of their harvest, depending on the type of crop, sometimes as much as two-thirds of the harvest; and

- tenants who paid in the form of labour.

Agrarian relations in the Near East can be divided into three broad categories: patronage; partnership and exploitation (Oakman 1986:56; Fiensy 1991:80-82). The landlord of the aris shared his risk. By contrast, the hocar took all risks himself. A free peasant could lose control over his land and could become a tenant. The land could be added to that of a member of the elite. For the purposes of this study, the concept of tenancy is important, because tenancy was a typical mechanism by means of which a peasant could be trapped in a dependent relationship (enslavement - GV). Sometimes, the land was no longer suited to self-sufficiency and subsistence farming by peasants and their families. Taxes might have risen too much, or it was a bad year, so that the peasant(s) had to borrow from of the great landowners. This meant that the peasant then had to use his surplus to repay the landowner (Oakman 1986:55; Fager 1993:85).

The best explanation for the loss of peasants' land is probably the investment that the Judaean and Galilean aristocracy began to make in land. An asymmetric power relationship arose, and peasants were trapped in this system, and eventually they were forced to lease land from the big landowners. When the situation became unendurable, the peasant was dispossessed of land he had inherited and his land was given to another landowner. Of course, this meant that big landowners' estates simply continued to increase in size. Thus land was taken in lieu of payment where a peasant could not pay his debts. This transfer of land did not involve a physical transfer - instead, it meant that control (ownership) of the land was transferred to the owners of large estates. The peasant and his family often stayed on the land as tenants. In the Herodian period, debt was rife in Palestine. Loans and the purchase of land were the only forms of investment open to the rich. The New Testament (see Mt 18:23-24) indicates that debt was a 
problem in the Herodian period. The fact that the Sicarii burnt the letters of debt in Jerusalem during the Jewish war is also indicative of such an enslaving situation (Oakman 1986:55, 56; Fiensy 1991:78, 79). The other way to obtain land was simply to move the boundaries of the estate, or to threaten the peasant or to use force to make him sell the land or to move. Aristocrats also obtained land by means of counterfeit /fraudulent contracts. The trend seen elsewhere in the Roman Empire to put more and more land in the hands of a minority also emerged in Palestine (Fiensy 1991:79).

The bureaucracy developed the administration and the process of registration into a science. The tax returns could be calculated in advance. The state's share was always received as per agreement, in spite of plagues, droughts or disaster. The elite claimed their rent and tax and attempted to increase their income by levying additional taxes. This confirms that there was a hierarchy of landlords who exercised their rights with regard to the yield of their land. Fiensy (1991:83) points out that the relationship between a landlord and his tenants varied depending on the individual landlord's character and temperament. Frequently, there was a hostile and distrustful relationship between the tenant and the landlord and it has been suggested that some tenants were beaten to coerce them to pay what they owed their landlord.

The tenants were also highly dependent on their landlords; not only for the use of the land, but also for food, seed and agricultural implements. Everything that they borrowed from their landlord weakened tenants' position when the harvest was brought in. As soon as the harvest was on the threshing floor, everyone who had some claim to the harvest moved in to stake a claim. Landlords took not only their own share, but also took back all the grain or seed that the tenant had borrowed. Sometimes the landlord dictated the entire contract, and the peasant was completely at the mercy of his landlord's whims (Fiensy 1991:83).

What was a peasant's quality of life? The hocar and the socar worked relatively large farms and probably led a fairly comfortable life during good times. But in bad years, their life would have been very hard. The aris were usually relatively poor and were therefore entitled to the benefits open to the poor. Most of them were slaves, to all practical purposes (Fiensy 1991:84). 


\subsection{Level of self-sufficiency}

Oakman (1986:58-72) attempted a quantitative study of the taxes and rent levied on resources (land) and payable by the peasants, and he attempts to place these elements in perspective. He operates from the assumption that an adult man needs 10 bushels of grain per year or 2500 kalories per day. Without taking into account children, there were 3 to 6 acres of land for every adult. These are the sizes of the plots, and not the amounts of land needed for subsistence. More or less half of every estate had to lie fallow every year. The land was subject to tax. A subsistence plot of a plot for self-sufficiency was 1,5 acres per adult. Enough grain could be produced on a piece of land of this size in a good year for one adult. The yields obtained from a given piece of land depended on the type of land and soil, the availability of water, the amount of seed sown and other variables such as the weather. Most regions in the Mediterranean produced a fivefold yield.

The peasants also kept livestock. They also had to make some provision for feeding these animals. During the summer when the fields lay fallow, the animals were allowed to graze in the fields. This helped to keep the grass short and provided the manure needed to keep the land fertile. During the planting and growth months the livestock was a threat to the crops and the animals were kept fenced off. Later, the livestock was driven into the mountains during the winter. During the harvest season, livestock were used in the threshing process or to run the presses and they were allowed to eat the hay. It is clear that peasant families in Palestine tried to be as self-sufficient as possible. The people in a village formed an extended family. They bartered labour and services to ensure mutual dependence. This mutual assistance in a village was carefully monitored and controlled. The system was known as balanced reciprocity. The degree of self-sufficiency was not limited only to the village. It depended on the degree to which the village economy was connected to the regional economy, or even contributed to the greater Mediterranean economy.

The peasants thus had to maintain adequate reserves to barter or to purchase the services of outside artisans. In the rural areas in Palestine there were a number of specialist artisans such as tanners, potters, carpenters, weavers, leather workers and others. One tenth of the harvest gathered by every peasant in Palestine went to the temple 
(Dt 14:22). This tenth was the minimum religious expenditure. When grain first had to be converted into money, changes in the exchange rate or the value of money caused further complications (Dt 14:25), particularly for peope who lived far from the temple. Furthermore, three tenths had to be spent on replacement costs, domestic expenses, and religious or ceremonial expenses.

\section{THE LEVEL OF DEBT}

If a peasant fell behind in any of his payments, irrespective of whether the obligation concerned was tax, rent, customs or excise duties, domestic or replacement costs, he no longer had enough reserves to be self-sufficient and the peasant was forced to borrow to make up the shortfall. In exchange, he had to provide some form of security/guarantee in the form of property, his land or himself or a member of his family. Debt and agrarian problems played an important role Graeco-Roman historical developments. This is why remission of debt and redistribution of land became standard demands in ancient revolutionary movements. Debt had a devastating effect on Israelites.

The level of mortgages on land and the emergence of leasing instead of free estates in early Roman Palestine needs to be determined. One possible explanation for the phenomenon is the fact that the influx of wealth in Jerusalem from trade and business related to the temple resulted in a lot of surplus capital in the hands of the pro-Roman aristocracy (cf Goodman 1982:417-427). This wealth was used for loans to peasants living a precarious existence or to purchase more land. Both small independent farmers and artisans and urban plebeians in Jerusalem fell into debt, because rich land owners wanted to invest their surplus income profitably, and because the poor needed loans to survive. This background is only part of the picture. It does not explain why peasants were obliged to borrow money. The factors that led to debt or enslavement are described by Oakman (1986:74-77).

\subsection{Overpopulation}

First century life included production, distribution (trade) and consumption. While this economy was characterised by self-sufficiency, there was a tendency to large surplusses. Increased surplusses stimulated population growth. This meant that during this time, 
population growth became an increasingly important economic factor. Increased population growth required increased agricultural activity; consequently, more land was cultivated (Crosby 1988:22). Overpopulation reduced the size of the agricultural units farmed by Israelite peasants and these peasants' margins of survival were threatened (Oakman 1986:74).

\subsection{The effects of natural phenomena}

A debt situation could result from poor rainfall or successive poor harvests due to other natural causes, such as human or natural disasters. During the Herodian period there were two droughts and concomitant famines. Furthermore, locusts and wind made life difficult for the farmers. At such times grain prices increased sixteenfold. Large grain producers stockpiled grain to push up the prices and peasants streamed to the villages to beg. War and the mobilisation of troops, and depredations by robbers affected the lives of these peasants deeply. The unrest that arose after the death of Herod and the great revolt also played a role. Not only were these people facing the possibility of death from all quarters, but they knew that their entire harvest could be confiscated (Fiensy 1991:98). Although most people lived on or below the breadline, the human causes of disaster were primarily linked to increasing levels of debt.

\subsection{Demanding levies and expenses}

The urban aristocracy made more and more demands on the peasants while they themselves had surplus funds to invest or lend to others. The elite demanded tenths and levies. The Roman state made its own demands. This combination of factors forced the peasants to borrow money, resulting in a debt problem. A byproduct of large levies on the population was the concentration of land (in the hands of the elite - GV). There are several indications that dishonest members of the land-owning class in Jerusalem exploited debt contracts to blackmail peasants to give up their land. There was a marked increase in the number of large estates in early Roman Palestine. By contrast, there was also an increase in the number of tenants on the land of others (elite landowners - GV).

The enslavement of the peasants by means of debt and the fact that their land was disowned often led to martial conditions. Oakman (1986:76) points out the activities of 
the first century bandits and the sicarii in Palestine. The question then arises: How can the messianic movements and other forms of social unrest (for example, the actions of Judas) be explained, as opposed to the enslavement due to levies or the real conditions of economic enslavement (debt)? Fiensy (1991:76) points out that leases varied from half to two-thirds of the harvest. It was never less than a third of the harvest. Where it was a fixed amount, in relation to the harvest it could turn out to be an unbearably high percentage. We can deduce from the tenants' reaction how this issue affected them. There were a number of peasant revolts in the Roman Empire. Tenants certainly complained that they were being forced to pay more for their leases than had been agreed. They were even beaten to force them to pay. They threatened to leave their farms and go to seek work elsewhere. The landlord-tenant relationship meant that the landlord had authority over tenants and demanded rent. There was a power imbalance that meant that the tenant not only had to meet his landlord's nutritional needs, but was also an important source of his wealth (Oakman 1986:76, 77; Fiensy 1991:76, 77).

\subsection{Increasing cash levies}

When levies were absent, the elite were forced to ask rent in the form of hard cash, instead of asking for goods or services. Levies in the form of favours were also later changed to cash levies in Palestine. Some peasants' debt loads simply became bigger and bigger and they eventually gave up any attempt to pay their debt. The consequences of the shift to cash levies and leases in agrarian communities was disastrous: money, loans, non-payment and a calling in of mortgages/foreclosure followed (Oakman 1986:76).

\subsection{Taxes}

Two types of tax can be distinguished: direct and indirect tax. Direct tax was levied directly on the land or per capita. This type of tax included all toll fees, customs and excise, market taxes, estate duties - all of which drew money away from the agrarian and commercial sectors. It would appear that the land in Judaea which was originally farmed by Judeans only came to be seen as the property of the Roman state after $70 \mathrm{CE}$, when it was exposed to intensive exploitation by the Romans. The land was largely bought up by foreign owners, rented out and severely exploited. Before that time, the Romans 
respected Israelite land laws and Israelite laws of inheritance. Before $70 \mathrm{CE}$ tax was not a form of direct rent payable by Jews to the Roman state. The ruling families who collected tax for the Romans regarded tax as maintaining the Pax Romana and as guaranteeing that they would share in the benefits of this arrangement. However, Palestinian peasants would have needed to have a short memory to believe this. The Romans imposed strenuous taxes on the Israelites and this caused great bitterness among the Israelites. In spite of all the problems regarding the change of measures and monetary exchange rates among others (see Oakman 1986:69), land tax and the harvest taxes could be calculated at a tenth. Most agrarian states claimed between a tenth and half of agricultural production as tax. It was assumed that the peasants in Palestine paid a quarter to one third of their production in taxes. The final calculation proposes a minimum and a maximum total: the minimum tax paid was half of the yield and the maximum paid was two-thirds. If other social expenses and the replacement fund are added on and are deducted from production, that leaves one fifth or one thirteenth for the provision of the peasant's own needs. At best, then, a peasant got only what he had sowed (if the return he may keep is calculated at a fifth). Fiensy (1991:99-105) and Hanson \& Oakman (1998:113-125) provide a thorough overview of the heavy taxes that had to be paid under Roman occupation. The tributum soli (land tax) under Seleucid rule was a third of the grain and half of the fruit yield. The most common tax rate was one tenth and higher taxation was probably a punitive measure.

In 6 CE Judaea, Edom and Samaria fell under direct Roman control and after 44 CE Galilee and Perea did too. The usus fructus was paid for the use of the land and for the harvest. The normal tax was probably $10 \%$ to $12 \%$. If the Egyptian model was also applied in Palestine, Herod's favourites paid no tax, or paid tax at a reduced rate. Josephus' own land was initially taxed, but later he was exempted from tax as a form of high honour paid to a privilged individual.

The second type of tax paid by Palestinian farmers was the tributum capitis. In Syria every man between the ages of 14 and 65 and women between the ages of 12 and 65 had to pay this tax. A sensus was held from time to time to levy this tax. The amount payable varied between 40 drachmas per person for peasants and 20 drachmas each for the privileged class; to 16 and 12 for the two groups respectively. There were some officials in Egypt who did not pay any tax. 
For the rich, the tributum capitis was set at $1 \%$ of their movable assets. The poor had to pay this tax on the body (which also belonged to the state). The average tax for the poorer farmers in Palestine was probably one drachma per person per year (see Mk 12:13-17). Indirect taxes were also levied, for example on salt, toll, trade taxes and, for those who lived in Jerusalem, a house or poll tax. Taxes were collected by the telonai on a tender basis. In addition to a peasant's obligations to the state, there were as many as twelve types of religious taxes. However, it would appear that most peasants in Palestine did not pay these taxes.

The term am ha-aretz was used in the Rabbinical era as a (religious) distinction from the habirim. The am ha-aretz seldom paid their tenths, but probably had to pay the grain sacrifice. The peasants had to pay an average of $12 \%$ of their harvest as land tax, one dinarius per person over the age of 14 years per year and about a fortieth of the harvest to the grain sacrifice. This claims about $15 \%$ of the annual harvest yield. Another $20 \%$ had to be put aside as seed for the next year's crop, because the land produced a fivefold yield. His family's needs required $65 \%$ of the yield for food, and when a peasant had paid his tenth, only $55 \%$ was left. This was similar to the yield of a tenant who farmed for two-thirds of the harvest yield.

The living standards in Galilee were higher than those in Judaea, because there may have been fewer landlords. However, poor Galileans tended to go to Judaea to look for work. Jesus' focus on the poor suggests there was also poverty in Galilee. The hatred of the Galileans for cities such as Tiberias and Sephoris suggests that the aristocrats in those cities exploited the poor. More or less the same socio-economic conditions existed in Galilee during the Herodian period (Fiensy 1991:104, 105). The socio-economic situation in Palestine in the early empire changed to debt, the concentration of land in the hands of the elite and an increase in the leasing of land to tenants by absent landlords.

\section{CONCLUSIONS}

The Biblical jubilee can be understood within the broad frame of reference of the Kingdom of God and the redemption in and through Jesus Christ. The acceptance of the confession of the reign of God leads to liberation from all types of enslavement and debt. There is no direct reference to the jubilee in the Gospels. The preaching of the Gospels is 
closely related to involvement with social outcasts. The messages of liberation (manumission) and remission of debt are integral parts of the Biblical jubilee, as is the gospel message of Jesus regarding God's reign. The Kingdom of God breaks down all forms of social, political and economic enslavement.

Sociology of knowledge examines the jubilee within the context of the world views held in first century Palestine. Individuals and society were parts of a dialectic relationship: people influence the social world and are in their turn shaped by their social world (intersubjective dependence $-\mathrm{GV}$ ). The social order was legitimised by processes and institutions that together form a shared frame of reference. The nucleus of a sociology of knowledge study is the dialectic tensions between descriptive and normative aspects of the construction and maintenance of the universe. A moral world view includes those symbols that organise values into a system that guides uniform behaviour in society. The objective meaning focuses on two conflicting views of land ownership (land as a tradable commodity versus land as an inalienable heirdom). Expressive meaning refers to the priests' perception of the return to the land. The documentary meaning emphasises divine ownership of the land.

Oakman (1986) examines first century economy by means of a social scientific approach within the context of a comprehensive socio-historical framework. In such a framework, this study focuses on labour and land ownership. A clear description was given of various types of land ownership and tenancy. The description of the relationship between landlords and tenants suggest exploitation and financial enslavement. Land was increasingly accumulated in the hands of the elite, who were absent landlords. First century Palestinian economy was a subsistence economy with extended families that had to be self-sufficient. Debt and levies enslaved these peasants, placing their families under pressure.

\section{Works consulted}

Berger, P L 1969. The sacred canopy: Elements of a sociological theory of religion. Garden City NY: Doubleday.

Berger, P L \& Luckmann, T 1967. The social construction of reality: A treatise in sociology of knowledge. New York: Doubleday. 
Brueggemann, W 1986. The earth is the Lord's. Sojourners 15, 15-45.

Crosby, M H 1988. The house of disciples: Church, economics and justice in Matthew. New York: Orbis Books.

Fager, J F 1993. Land tenure and the Biblical Jubilee: Uncovering Hebrew ethics through the sociology of knowledge. (JSOT Supplement Series 155.)

Fiensy, D A 1991. The Land is mine: The social history of Palestine in the Herodian period. Lewiston, NY: Edwin Mellen. (Studies in the Bible and Early Christianity 20.)

Flanagan, J W 1988. David's social drama: A hologram of Israel's early iron age. Sheffield: Almond Press. (The Social World of Biblical Antiquities Series, 7.)

Geertz, C 1974. The interpretation of culture: Selected essays. New York: Basic Books.

Gnuse, R 1985. Jubilee legislation in Leviticus: Israel's vision of social reform. BTB 15 , 43-48.

Goodman, M 1982. The first Jewish revolt and the problem of debt. Journal of Jewish Studies 30, 417-427.

Hanson, K C \& Oakman, D 1998. Palestine in the time of Jesus: Social structures and social conflicts. Minneapolis: Fortress.

Hollenbach, P W 1985. Librating Jesus for social involvement. BTB 15(4), 151-157.

Malina, B J 1982. The social sciences and Biblical interpretation. Interpretation 36(3), 229-242.

Mannheim, K 1936. Ideology and utopia: An introduction to the sociology of knowledge, tr by L Wirth \& E Shils. New York: Harcourt Brace Jovanovich.

North, R 1954. Sociology of the Biblical jubilee. Rome: Pontifical Biblical Institute.

Oakman, D 1986. Jesus and the economic questions of his day. Lewiston: Edwin Mellon. (SBEC 8.)

Ringe, S H 1985. Jesus, liberation, and the Biblical jubilee: Images for ethics and Christology. Philadelphia: Fortress.

Wright, C J H 1990. God's people in God's land: Family, land, and property in the Old Testament. Grand Rapids: Eerdmanns. 